\title{
Phenobarbitone: Indian Epilepsy Society- Consensus Document
}

\author{
Man Mohan Mehndiratta ${ }^{a}$, Satish Jain ${ }^{b}$, Parampreet S. Kharbanda ${ }^{c}$, \\ Pravina Shah ${ }^{d}$, Manjari Tripathi ${ }^{e}$, Sita Jayalakshmi ${ }^{f}$, Sheffali Gulati ${ }^{g}$, \\ Suvasini Sharma ${ }^{h}$, Sangeeta Ravat ${ }^{i}$ \\ a Janakpuri Super Speciality Hospital, New Delhi \\ ${ }^{\mathrm{b}}$ Indian Epilepsy Centre, New Delhi \\ ${ }^{\mathrm{c}}$ Postgraduate Institute of Medical Education \& Research (PGIMER), Chandigarh \\ ${ }^{\mathrm{d}}$ Fortis Hospital, Mulund, Mumbai, Maharashtra \\ e All India Institute of Medical Sciences New Delhi \\ ${ }^{\mathrm{f}}$ Krishna Institute of Medical Sciences, Secunderabad, Telangana \\ ${ }^{g}$ All India Institute of Medical Sciences, New Delhi \\ ${ }^{\mathrm{h}}$ Lady Hardinge Medical College and Associated Kalawati Saran Children's Hospital, New Delhi \\ ${ }^{\mathrm{i}}$ Seth G.S. Medical College and King Edward Memorial Hospital Mumbai
}

\begin{abstract}
Epilepsy is a common neurological disorder affecting 65 million people worldwide and approximately more than 12 million in India. Two-third of the people with epilepsy lives in resource-limited countries. Phenobarbitone was the first antiepileptic drug (AED) used in 1912 and has been in use for more than 100 years now. Its low cost and favorable cost-efficacy ratio, which is lower than any other AED in current use, makes the drug particularly suitable for use in the low- and middleincome countries. [1] The World Health Organization (WHO) recommends phenobarbitone as a first-line treatment for convulsive seizures in resource-poor countries and includes it in its Essential Drug List. [2] However, the use of phenobarbitone is largely limited owing to the concerns regarding its cognitive and behavioral side effects especially in children. This article summarizes the current role of phenobarbitone in the treatment of epilepsy.
\end{abstract}

Tables 1-5

\section{Recommendations}

The Indian Epilepsy Society has the Guidelines in the Management of Epilepsy in India (GEMIND) where phenobarbitone is mentioned as a first-line drug in the management of all types of epilepsy other than absence seizures. The recommendations are based on the information collated from the key studies and systematic reviews related to Phenobarbitone.

\section{Mechanism of Action}

Phenobarbitone interacts with $\gamma$-aminobutyric acid-A (GABAA) receptors and facilitates GABA-mediated inhibition via allosteric modulation of the receptor. It inhibits epileptic activity by other mechanisms such as - increase in chloride-influx leading to hyperpolarization of the postsynaptic neuronal cell membrane [3,4]; blocking high-frequency repetitive firing of neurons; and reduction in glutamate or aspartate-induced depolarization [5].

\section{Pharmacokinetics}

- Phenobarbitone can be administered by both parenteral (intravenous and intramuscular) and oral routes.

- It is rapidly absorbed and distributed to all tissues and fluids with high concentrations in the liver, kidneys and heart.

- It reaches peak plasma concentration after 0.5-4 h after oral dosing and 2-8 $\mathrm{h}$ after intramuscular administration.

- The drug has long half-life, approximately 3-5 days in adults and 1.5 days in children so it is usually given as once daily dose and poses low risk of withdrawal seizures. 
Table 1 - Comparison of various studies listing problems with the use of phenobarbitone.

\begin{tabular}{|c|c|c|}
\hline Study (year) & Subjects & Comments \\
\hline Mani et al (2001) & 135 (phenobarbitone: 55) & $\begin{array}{l}4 \% \text { on phenobarbitone while } 43 \% \text { on } \\
\text { PHT had adverse effects }\end{array}$ \\
\hline Wang et al (2006) & 2455 (phenobarbitone) patients & Phenobarbitone was well tolerated \\
\hline $\begin{array}{l}\text { Satishchandra } \\
\text { et al (2014) }\end{array}$ & $\begin{array}{l}75 \text { ( } 63 \text { completed) adult } \\
\text { patients with newly } \\
\text { diagnosed epilepsy-prospective } \\
\text { multi-centric study }\end{array}$ & $\begin{array}{l}\text { No worsening of cognitive or psychological } \\
\text { functioning; good seizure control improvement } \\
\text { in attention, executive functions, learning, memory, } \\
\text { and intelligence. Self-report of cognitive impairment } \\
\text { consequent to the epilepsy and its treatment showed } \\
\text { a decrease. No deterioration in daily activities } \\
\text { and depression. }\end{array}$ \\
\hline Meador et al (1995) & $\begin{array}{l}59 \text { healthy adults received } \\
\text { phenobarbitone, PHT or VPA }\end{array}$ & $\begin{array}{l}\text { Those on phenobarbitone were worse (not significant) } \\
\text { than either PHT or VPA, PHT and VPA were comparable. }\end{array}$ \\
\hline $\begin{array}{r}\text { Tudur Smith } \\
\text { et al (2003) }\end{array}$ & 684 patients & $\begin{array}{l}\text { Phenobarbitone and CBZ did not differ for the outcomes } \\
\text { of 'time to } 12 \text { month remission' and 'time to first seizure' } \\
\text { phenobarbitone more likely to be withdrawn indicating less tolerance as } \\
\text { compared with CBZ. }\end{array}$ \\
\hline Feksi et al (1991) & 302 (249 completed the study) & $\begin{array}{l}53 \% \text { seizure-free low drop-out rate, low rate of withdrawal due to adverse } \\
\text { effects and acceptable compliance. }\end{array}$ \\
\hline
\end{tabular}

- Therapeutic drug levels of phenobarbitone $=10 \mathrm{mg} / \mathrm{L}$ to $40 \mathrm{mg} / \mathrm{L}$. [6]

- It undergoes auto-induction and increases its own clearance, therefore requires an upward dose adjustment when prescribed as monotherapy.

\section{Spectrum}

- It is a board spectrum AED used clinically in neonatal seizures, status epilepticus (SE), focal and generalized tonicclonic seizures, febrile seizure (continuous prophylaxis), and as add-on in refractory epilepsy.

- Absence seizures however do not respond to phenobarbitone and may be aggravated. [7]

- It has also been found useful in the treatment of juvenile myoclonic epilepsy. [8]

\section{Table 2 - Few Examples of Drug Interactions Involving} Phenobarbital.

\begin{tabular}{ll} 
Acetazolamide & Increase Phenobarbital levels \\
\hline Phenytoin & Increase Phenobarbital levels by \\
& $50-70 \%$ \\
& $30-50 \%$ increase in Phenobarbital \\
Valproic acid & levels \\
& Increase Phenobarbital levels by \\
Oxcarbazepine & $15 \%$ at doses $>1200$ mg/day \\
& Phenobarbital enhances \\
Clobazam & metabolism of clobazam \\
& Failure of oral contraceptives \\
Oral contraceptives & Phenobarbital induces metabolism \\
Warfarin & of warfarin \\
& Decrease levels of drugs by \\
Steroids, antimicrobials, & phenobarbital \\
antineoplastic drugs &
\end{tabular}

\subsection{Adverse Effects}

- Like most other AEDs, phenobarbitone is associated with dose-dependent adverse effects.

- Although phenobarbitone demonstrates overall tolerability similar to that of other established AEDs, and serious systemic side effects are uncommon, its potential for neurobehavioral toxicity remains a topic of major concern.

- Sedation and hypnosis are the principal side effects of phenobarbitone.

\section{Table 3 - Pharmacokinetics of Phenobarbital.}

\begin{tabular}{|c|c|}
\hline Indication & $\begin{array}{l}\text { Partial and generalized } \\
\text { tonic-clonic seizures } \\
\text { neonatal seizures; status } \\
\text { epilepticus, febrile seizures }\end{array}$ \\
\hline Not useful & Absence seizures \\
\hline Mechanism of action & Enhance GABA inhibition \\
\hline Bioavailability & $>95 \%$ \\
\hline $\begin{array}{l}\text { Time to peak levels } \\
\text { after single dose }\end{array}$ & $0.5-4 \mathrm{~h}$ \\
\hline Protein binding & $45-60 \%$ \\
\hline Elimination half-life & $\begin{array}{l}\text { 3-5 days (adults), } 1.5 \text { days } \\
\text { (children) }\end{array}$ \\
\hline Main routes of elimination & $\begin{array}{l}\text { Hepatic metabolism; CYP } 450 \\
\text { inducer } \\
25 \% \text { renally excreted unchanged }\end{array}$ \\
\hline Maintenance dose & $\begin{array}{l}\text { Children: } 4-8 \mathrm{mg} / \mathrm{kg} / \text { day } \\
\text { Adults: } 60-240 \mathrm{mg} / \text { day }\end{array}$ \\
\hline Volume of distribution & $0.42-0.73 \mathrm{~L} / \mathrm{kg}$ \\
\hline Daily doses & $1-2$ \\
\hline Target plasma concentration & $10-40 \mathrm{~g} / \mathrm{mL}$ \\
\hline Clearance & $\begin{array}{l}\text { Age }>40 \text { years, total clearance: } 2.5 \\
\mathrm{~mL} / \mathrm{kg} / \mathrm{h} \\
\text { Age } 15-40 \text { years, total clearance: } \\
4.9 \mathrm{~mL} / \mathrm{kg} / \mathrm{h} \\
\text { Age } 8 \mathrm{months} \text { to } 4 \text { years, total } \\
\text { clearance: } 5.3-14.1 \mathrm{~mL} / \mathrm{kg} / \mathrm{h}\end{array}$ \\
\hline
\end{tabular}


Table 4 - Side-effect Profile of Phenobarbitone.

\begin{tabular}{ll} 
Relatively common & Uncommon \\
\hline $\begin{array}{l}\text { Neurobehavioral } \\
\text { Sedation }\end{array}$ & $\begin{array}{l}\text { Megaloblastic anemia } \\
\text { Osteomalacia } \\
\text { Behavior }\end{array}$ \\
$\begin{array}{l}\text { Hyperactivity } \\
\text { Changes in mood and affect }\end{array}$ & \\
$\begin{array}{l}\text { Adverse effect on cognition } \\
\text { Connective tissue disorders }\end{array}$ & \\
$\begin{array}{l}\text { Dupuytren's contracture } \\
\text { Frozen shoulder }\end{array}$ & Aggravation of porphyria \\
\hline $\begin{array}{l}\text { Modified and adapted from: Kwan P, Brodie JM. Epilepsia 2004; } \\
\text { 45:1141-9 }\end{array}$ & Teratogenicity \\
\hline
\end{tabular}

\section{Table 5 - Phenobarbitone in Status Epilepticus.}

Indication

Convulsive SE, nonconvulsive SE in children and adults, refractory SE

\begin{tabular}{|c|c|}
\hline Bioavailability & Approximately $95 \%$ \\
\hline Standard dosage in SE & $20-40 \mathrm{mg} / \mathrm{kg} /$ day \\
\hline \multicolumn{2}{|l|}{ Maintenance dose: } \\
\hline In children & $4-8 \mathrm{mg} / \mathrm{kg} /$ day \\
\hline In adults & $60-240 \mathrm{mg} / \mathrm{kg} /$ day \\
\hline Route of elimination & $\begin{array}{l}\text { Metabolized in liver; } \\
\text { one-fourth excreted } \\
\text { unchanged in urine }\end{array}$ \\
\hline \multirow{5}{*}{$\begin{array}{l}\text { Advantages of } \\
\text { phenobarbitone }\end{array}$} & Estimated efficacy of $73.6 \%$ \\
\hline & Broad spectrum of action \\
\hline & Comparative efficiency with other \\
\hline & AEDs \\
\hline & Neuroprotective effect \\
\hline Common adverse effects & $\begin{array}{l}\text { Respiratory depression, } \\
\text { hypotension, severe sedation }\end{array}$ \\
\hline
\end{tabular}

- In elderly patients, it may cause excitement and confusion, while in children it may result in paradoxical hyperactivity.

- Careful evaluation of the randomized control trials does not provide convincing evidence for an excess of behavioral adverse effects, compared to other AEDs. [9]

\subsection{Phenobarbitone in Childhood Epilepsy}

- There is not sufficient evidence to establish the use of phenobarbitone in childhood epilepsy. [Based on the level of evidence from The International League Against Epilepsy (ILAE) Task Force 2013]

- Phenobarbitone is considered to be probably effective as initial monotherapy in children with focal onset of seizures, generalized tonic and clonic seizures. [10]

- Phenobarbitone may aggravate or precipitate absence seizures. [11]

- In children with refractory focal epilepsy, phenobarbitone can be considered as an additional therapy by a tertiary epilepsy specialist after use of first-line AEDs and adjunctive AEDs (National Institute for Clinical Excellence [NICE] 2012). [12]
- Phenobarbitone can be used as a second-line agent after benzodiazepines in treatment of convulsive SE in children and after glucose and calcium in neonates.[10,12]

- Several anecdotal case reports demonstrate successful usage of very high dose of phenobarbitone in the management of refractory SE in children.

\subsection{Phenobarbitone in Neonatal Seizures}

- Phenobarbital should be used as the first-line agent for treatment of neonatal seizures.

- In neonates with birth asphyxia, prophylactic usage of phenobarbitone is not recommended.

- Phenobarbitone in Febrile Seizures

- Prophylactic treatment with intermittent antipyretics, intermittent anticonvulsant (diazepam or clobazam), or continuous anticonvulsant (phenobarbitone or valproic acid) should not be considered for simple febrile seizures.

- Phenobarbitone may be effective at reducing febrile seizure recurrence in children with a history of simple or complex febrile seizures with risk of behavioral problems such as hyperactivity, irritability, aggression, and cognitive impairment. $[13,14]$

- Intermittent diazepam or continuous phenobarbitone may be no more effective at reducing the risk of subsequent epilepsy in children with febrile seizures.[13,14]

- The evidence is inconclusive whether phenobarbitone is more effective than sodium valproate (VPA) at reducing the proportion of children with febrile seizure recurrence.7

\subsection{Phenobarbitone in Status Epilepticus (SE)}

- A substantial number of physicians prescribe phenobarbitone as the initial line of treatment for generalized convulsive status epilepticus (GCSE). [15]

- In a study evaluating the treatment efficacy of initial management of GCSE by phenobarbitone, diazepam plus phenytoin, phenytoin, and lorazepam, it was found that phenobarbitone was no less effective than lorazepam (the best AED) in control of overt GCSE. [16] The same study also observed that phenobarbitone is similar to other AEDs in protecting against recurrence of GCSE over $12 \mathrm{~h}$ time period. Moreover, in the study population, the risk of AED-related adverse events was similar across all the four drug groups. Furthermore, in nearly half of the patients, phenobarbitone was successful as the first-line therapy.

- The loading dose of phenobarbitone in SE is $20-40 \mathrm{mg} / \mathrm{kg}$ and the maintenance dose is $4-8 \mathrm{mg} / \mathrm{kg} /$ day in children and is $60-240 \mathrm{mg} /$ day in adults given at 1-2 daily doses with a target plasma concentration of $10-40 \mu \mathrm{g} / \mathrm{mL} .6$

- In patients where the SE is resistant to first-line administration of benzodiazepines, phenobarbitone has been extensively used effectively as the next line of therapy. A study of meta-analysis of literature has recently suggested that phenobarbitone has an estimated efficacy of $73.6 \%$ (95\% CI: 58.3-84.8\%). [17] Significant advantage of phenobarbitone in addition to this efficacy is its potential neuroprotective effect. 
- The efficacy of levetiracetam was reported to be lower than the efficacy of phenobarbitone.

- There is no sufficient evidence to demonstrate the superiority of VPA over phenobarbitone in the management of convulsive SE. [18] Phenobarbitone is one of the second-line AED in the management of convulsive SE.

\subsection{Phenobarbitone in Refractory Status Epilepticus}

- Refractory SE is associated with high morbidity and mortality.

- Phenobarbitone has been reported to be highly effective in the management of refractory SE.

- Very high dose of phenobarbitone is effective in the management of adult and elderly patients with RSE. [19]

- Very high dose of phenobarbitone (30-120 mg/kg) is effective in seizure control with milder side effects than thiopental infusion in childhood RSE. [20,21]

\subsection{Effect of Phenobarbitone in Pregnancy}

- Phenobarbital readily crosses the placenta and plasma concentrations in neonates are similar to those in the mother.

- Data from the European and International Registry of Antiepileptic Drugs and Pregnancy (EURAP) registry shows occurrence of congenital malformations. [22]

- Phenobarbital is associated with congenital anomalies such as dysmorphic face, Fallot tetralogy in heart, hydronephrosis, inguinal hernia with umbilical hernia, and congenial dislocation of the hip when exposed during the first trimester of pregnancy.

- Use of Phenobarbitone in Developing Countries

- The studies conducted in developed countries show neurobehavioral toxicity caused by phenobarbitone leads to high discontinuation rates of the drug, whereas when the drug is used in developing world no such neurobehavioral toxicity is reported. [23]

- In India, the treatment gap in epilepsy varies from $40 \%$ in Kerala to $90 \%$ in West Bengal. [24] There is a need for an effective, affordable, and acceptable AED to reduce this treatment gap. Phenobarbitone is most suited for this role due to its good efficacy, broad spectrum of action, unique mechanism of action, and recent evidence has demonstrated a favorable cognitive-behavioral profile. [25]

- The negative reputation of phenobarbitone regarding tolerability comes more from its lack of a commercial sponsor than from a critical analysis of the available literature. [26]

\section{Conclusion}

With epilepsy affecting more than 60 million people worldwide and over $80 \%$ of them living in resource-limited countries, a low-cost AED such as Phenobarbitone can play a significant role as the most cost-effective treatment. Though the adverse effect profile is controversial but recent evidence suggests it may be better tolerated thansuggested by the earlier studies.

\section{National Advisory Board}

K.P. Vinayan, Sanjeev Thomas, P. Satishchandra, Atma Ram Bansal, Atam Preet Singh

Amrita Institute of Medical Sciences Kochi, Kerala, Sree Chitra Tirunal Institute for Medical Sciences and Technology Thiruvananthapuram, Kerala, National Institute of Mental Health \& Neuro Sciences (NIMHANS),Bengaluru, Karnataka, Medanta-The Medicity Gurgaon, Haryana

Fortis Hospital, Noida, Uttar Pradesh

A grateful thanks to all the group members involved in this endeavor to take out time from their busy schedule for this consensus Document.

Acknowledgement to following for peer review and valuable suggestion for this document.

Dr.Prof Martin J Brodie, Glasgow, U.K

Dr.(Prof) Patrick Kwan-Melborne, Australia

Dr. (Prof.)Abraham Kuruvilla, India

Dr. (Prof)Gagandeep Singh, India

\section{R E F E R E N C E S}

[1]. Ilangaratne NB, Mannakkara NN, Bell GS, Sander JW Phenobarbital: missing in action. Bull World Health Organ. 2012;90:. 871-871A.

[2]. World Health Organization. Division of Mental Health. Initiative of Support to People with Epilepsy. Geneva: World Health Organization, 1990.(document WHO/MNH/ MND/90.3).

[3]. Rogawski MA, Porter RJ. Antiepileptic drugs: pharmacological mechanisms and clinical efficacy with consideration of promising developmental stage compounds. Pharmacol Rev. 1990;42:223-286.

[4]. Twyman RE, Rogers CJ, Macdonald RL. Differential regulation of $\gamma$-amino butyric acid receptor channels by diazepam and Phenobarbital. Ann Neurol. 1989;25:213-220.

[5]. Seeman P. Membrane actions of anesthetics and tranquilizers. Pharmacol Rev. 1972;24:583-656.

[6]. Booker HE. Phenobarbital. Relation of plasma concentration to seizure control. In: Antiepileptic Drugs Woodbury DM, Penry JK, Pippenger DE, (Eds.), New York: Raven Press, 1982:341-50.

[7]. Wilmshurst JM, van Toorn R. Use of phenobarbitone for treating childhood epilepsy in resource-poor countries. S Afr Med J 2005; 95:392, 394, 396.

[8]. Gursahani R. Phenobarbitone in modern India. J Assoc Physicians India. 2013;61(8 Suppl):45-47.

[9]. Pal DK. Phenobarbital for childhood epilepsy: systematic review. Paediatr Perinat Drug Ther. 2006;7:31-42.

[10]. Glauser T, Ben-Menachem E, Bourgeois B, et al. Updated ILA. evidence review of antiepileptic drug efficacy and effectiveness as initial monotherapy for epileptic seizures and syndromes. Epilepsia. 2013;54:551-563.

[11]. Kwan P, Brodie JM. Invited review: phenobarbital for the treatment of epilepsy in the 21st century: a critical review. Epilepsia. 2004;45:1141-1149.

[12]. NICE guidelines update 2013. The diagnosis and management of the epilepsies in adults and children in primary and secondary care. Available at: http://www. 
nice.org.uk/guidance/cg137/resources/guidance-theepilepsies-the-diagnosisand-management-of-theepilepsies-in-adults-and-children-in-primary-and secondary-care-pdf.(Accessed on 12th October 2014).

[13]. Mewasingh LD. Febrile seizures. Clin Evid (Online) 2010;2010. pii: 0324.

[14]. Offringa M, Newton R. Prophylactic drug management for febrile seizures in children. Cochrane Database Syst Rev 2012:CD003031.

[15]. Goldberg MA, McIntyre HB. Barbiturates in the treatment of status epilepticus. Adv Neurol. 1983;34:499-503.

[16]. Treiman DM, Meyers PD, Walton NY, et al. A comparison of four treatments for generalized convulsive status epilepticus. Veterans Affairs Status Epilepticus Cooperative Study Group. N Engl J Med. 1998;339:792-798.

[17]. Yasiry Z, Shorvon SD. The relative effectiveness of five antiepileptic drugs in treatment of benzodiazepineresistant convulsive status epilepticus: a metaanalysis of published studies. Seizure. 2014;23:167-174.

[18]. Brigo F, Igwe SC, Nardone R, et al. A common referencebased indirect comparison meta-analysis of intravenous valproate versus intravenous phenobarbitone for convulsive status epilepticus. Epileptic Disord. 2013;15: 314-323
[19]. Tiamkao S, Mayurasakorn N, Suko P, et al. Very high dose phenobarbital for refractory status epilepticus. J Med Assoc Thai. 2007;90:2597-2600.

[20]. Lee WK, Liu KT, Young BW. Very-high-dose phenobarbital for childhood refractory status epilepticus. Pediatr Neurol. 2006;34:63-65.

[21]. Crawford TO, Mitchell WG, Fishman LS, Snodgrass SR. Very-high-dose phenobarbital for refractory status epilepticus in children. Neurology. 1988;38:1035-1040.

[22]. Tomson T, Battino D, Bonizzoni E, et al. EURAP Study Group. Dose-dependent risk of malformations with antiepileptic drugs: an analysis of data from the EURAP epilepsy and pregnancy registry. Lancet Neurol. 2011;10:609617.

[23]. Kwan P, Brodie MJ. Phenobarbital for the treatment of epilepsy in the 21st century: a critical review. Epilepsia. 2004;45:1141-1149.

[24]. Tripathi M, Jain DC, Devi MG, et al. Need for a national epilepsy control program. Ann Indian Acad Neurol. 2012;15:89-93.

[25]. Brodie MJ, Kwan P. Current position of phenobarbital in epilepsy and its future. Epilepsia. 2012;53(Suppl 8):40-46.

[26]. Kale R, Perucca E. Revisiting phenobarbital for epilepsy. BMJ. 2004;329:1199-1200. 